Article

\title{
Multi-Sensor Observation of a Saharan Dust Outbreak over Transylvania, Romania in April 2019
}

\author{
Nicolae Ajtai, Horațiu Ștefănie, Alexandru Mereuță, Andrei Radovici and Camelia Botezan * \\ Faculty of Environmental Science and Engineering, Babeș-Bolyai University, 30 Fântânele St., \\ 400294 Cluj-Napoca, Romania; nicolae.ajtai@ubbcluj.ro (N.A.); horatiu.stefanie@ubbcluj.ro (H.Ș.); \\ mereutaalexandru90@gmail.com (A.M.); radovici_andrei@yahoo.com (A.R.) \\ * Correspondence: camelia.costan@ubbcluj.ro
}

Received: 17 March 2020; Accepted: 8 April 2020; Published: 9 April 2020

\begin{abstract}
Mineral aerosols are considered to be the second largest source of natural aerosol, the Saharan desert being the main source of dust at global scale. Under certain meteorological conditions, Saharan dust can be transported over large parts of Europe, including Romania. The aim of this paper is to provide a complex analysis of a Saharan dust outbreak over the Transylvania region of Romania, based on the synergy of multiple ground-based and satellite sensors in order to detect the dust intrusion with a higher degree of certainty. The measurements were performed during the peak of the outbreak on April the 24th 2019, with instruments such as a Cimel sun-photometer and a multi-wavelength Raman depolarization lidar, together with an in-situ particle counter measuring at ground level. Remote sensing data from MODIS sensors on Terra and Aqua were also analyzed. Results show the presence of dust aerosol layers identified by the multi-wavelength Raman and depolarization lidar at altitudes of 2500-4000 m, and $7000 \mathrm{~m}$, respectively. The measured optical and microphysical properties, together with the HYSPLIT back-trajectories, NMMB/BSC dust model, and synoptic analysis, confirm the presence of lofted Saharan dust layers over Cluj-Napoca, Romania. The NMMB/BSC dust model predicted dust load values between 1 and $1.5 \mathrm{~g} / \mathrm{m}^{2}$ over Cluj-Napoca at 12:00 UTC for April the 24th 2019. Collocated in-situ PM monitoring showed that dry deposition was low, with PM10 and PM2.5 concentrations similar to the seasonal averages for Cluj-Napoca.
\end{abstract}

Keywords: Saharan dust; aerosol remote sensing; lidar; sun-photometer; MODIS

\section{Introduction}

Aerosols are an important component of the atmospheric mixture which influence radiative forcing through the atmosphere [1]. Besides the radiative effects, aerosols can pose a significant hazard to human health $[2,3]$ and to certain economic sectors, having a significant economic impact. In this case, similar to what took place in some Eastern and Western Asian countries, aerosols can affect constructions, aerial and terrestrial transportation (flight delay and traffic accident rate changes), trade, agriculture (crop degradation), manufacturing, and households over short and long term periods $[4,5]$.

Mineral aerosols are considered to be the second largest source of natural aerosol [6]. They usually originate from soil ablation in arid areas and are lofted to high altitudes by thermal turbulences and are subjected to long range transport $[7,8]$. Dust originating from the Sahara and Sahel regions of Northern Africa accounts for more than $50 \%$ of the global atmospheric mineral dust $[9,10]$. It is estimated that roughly 800 million tones/year of dust is subjected to aeolian transport from these two sources alone [11,12]. Upwards of $10 \%$ of these Saharan dust emissions are transported over continental Europe and the Mediterranean Sea [11]. Seasonal trajectories have been discussed in the scientific literature, with peak emissions observed in spring and summer [12,13]. Studies such as [14] show that transport over larger ranges are expected during April through June, while vertical transport is 
highest from April through September. Under certain meteorological conditions, significant amounts of Saharan dust are transported north, over the Mediterranean basin [15-17] and in severe cases, even over Western, Central, and Eastern Europe [18-21]. Dust outbreaks have been observed as far as northern Europe and the Baltic Sea [10,22]. Dust trajectories from North Africa to Continental Europe are often linked to the movement of two pressure systems. The strength and dynamics of these systems determine the potential to carry dust plumes over long ranges [22,23].

A severe dust intrusion can have intense socio-economic and environmental consequences. In previous studies, it was observed that the amount of Saharan dust in Romania can be above the threshold presented in the national legislation, which poses danger for human health [24]. Furthermore, a Saharan dust plume can influence the climate of Romania. Dust particles lofted above Romania are majorly mixed with pollutants of other European countries, and can easily lead to air pollution [25]. Concerning the additional environmental impacts of a dust intrusion, the $\mathrm{pH}$ of precipitations can increase due to the influence of Saharan dust events, similar to what took place in other European countries [26].

There is a need, at stakeholder level, for near-real-time monitoring and early warning systems. These systems could be developed for a region as extensive as Romania with the input of additional data sets from other sources [27]. With the integration of different data sets, information on the size and concentration of the dust particles, the dynamics of the dust plume, its altitude, etc. could be obtained. Generally, using different data from various sensors gives us the ability to comprehensively identify the dust intrusion's characteristics (that could not be performed using just a single sensor). The more information is sent to stakeholders, policy makers, and natural hazards specialists, the more accurate their decisions will become.

Therefore, in this paper, our main intention is to provide more information through multi-source data integration. In Romania there are several studies focusing on Saharan dust intrusions [28-31]. However, these studies were conducted in the southern and eastern part of Romania. In the north-western part of Romania, there is limited information on Saharan dust intrusions, with the majority of the studies carried out in this region [24,32,33] relying mostly on single-sensor information.

Due to the high degree of heterogeneity and spatial-temporal variability of atmospheric aerosols, the study of their composition, distribution, and dynamics is currently monitored at a global level. This monitoring can be ground-based, airborne or satellite-based.

Talianu et al., 2007 [34] detected a dust event over Bucharest, Romania, and also determined the dust type using a lidar system accompanied by a model data prognosis and air masses backward trajectories. Tudose, 2013 [25] studied a Saharan dust intrusion in Romania (occurred in July 2012) and its influences on the local weather using lidar data and complementary methods. Ajtai et al., 2017, [32] found that the aerosol properties over Cluj-Napoca, Romania derived from AERONET sun-photometric data using a CIMEL CE 318A radiometer. Labzovskii et al., 2014 [29] attempted to determine the properties of a Saharan dust intrusion (occurred in May and June 2013) over Bucharest (south of Romania) using lidar and sun-photometer. Ștefănie et al., 2015 [24] detected the dust intrusion over Cluj-Napoca, Romania (in April 2014) using a lidar system, FLEXPART and HYSPLIT models. They identified the source of the dust plume and measured the ground level concentration of dust particles using an optical aerosol monitor. Cazacu et al., 2017 [35] assessed the temporal and vertical variation of Saharan dust concentration near Bucharest, Romania (from the data related to 2012) using the lidar system and some auxiliary methods. Mărmureanu et al., 2019 [36] studied the synoptic-scale conditions leading to the Saharan dust intrusion that was mixed with snow precipitation (occurred in March 2018) over the south-east of Romania. They analysed the dust morphology, particle size, and the physical and chemical properties. They also developed a method that visualized the presence of some minerals. 
This paper contributes to the above-mentioned regional studies analyzing Saharan dust intrusions in the north-western part of Romania (which have not yet been sufficiently studied in this part of the country) using integrated, prevalent techniques and equipment types and satellite-based imagery. Thus, the integration of different datasets brings added value and leads to the extraction of valuable and more reliable information on the phenomenon of dust intrusions.

The aim of this paper is to provide a complex analysis of a Saharan dust outbreak over the Transylvania region of Romania based on the synergy of multiple ground-based and satellite sensors, in order to detect the dust intrusion with a higher degree of certainty. This outbreak occurred between April 21st and 25th 2019, affecting large areas of the European continent, reaching as far north as Iceland and Norway [37]. The exceptionally dust event was generated by a "haboob"- a cold low-pressure system, developed on 20th of April 2019 over north-west Africa (Morocco and Algeria). Significant amounts of dust were lifted up into the upper troposphere and then advected by the persistent southern circulation, at first towards Western Europe and western Mediterranean, and later on (starting on 23rd of April 2019) towards south-eastern Europe. Dust loaded air masses arrived over Transylvania, Romania on April the 24th 2019.

\section{Instruments and Method}

We analyzed data measured in Cluj-Napoca, Romania on April the 24th 2019 with a series of ground-based remote sensing instruments, such as multi-wavelength Raman depolarization lidar, part of the European Aerosol Research Lidar Network (EARLINET) [38], and a sun-photometer, part of the Aerosol Robotic Network (AERONET) [39]. Currently, the two networks are part of the Aerosols, Clouds, and Trace gases Research InfraStructure (ACTRIS) [40]. The Cluj-Napoca ACTRIS station can be considered representative for the whole Transylvanian territory, and also for the Pannonian Basin, given the limited coverage of AERONET and EARLINET in Hungary, Austria, and south-western Ukraine. Besides the ground-based instruments, remote sensing data from MODIS sensors on Terra and Aqua satellites were used in this analysis. During the intrusion, an in-situ optical particle counter measured particulate matter concentrations at ground level to account for potential dust deposition.

Each data source has some limitations. For example, the altitude information is not included in the MODIS product, but can be inferred from the lidar data. On the other hand, the two-dimensional distribution of dust is inferred by the MODIS images. By integrating these single sensor data products, new added value information will be extracted which could not have been collected by a single sensor.

\subsection{Cimel CE 318 Sun Photometer}

The Cimel CE 318 sun-photometer is a ground-based sun and sky tracking automated radiometer, which measures aerosol optical properties using a combination of filters and azimuth and zenith mobility. It measures sun and sky radiance in order to derive the aerosol properties. It provides aerosol optical depth at eight spectral channels in the wavelength range of $340-1640 \mathrm{~nm}$. It is a part of the AERONET [41]. The AERONET network provides two types of data: direct Sun spectral data based on the extinction of light through the atmospheric column (Aerosol Optical Depth (AOD), Ångström Exponent $(\alpha)$, SDA (Spectral Deconvolution Algorithm) Fine mode fraction, SDA Fine/Coarse AOD, etc.), and inversion data derived from the angular distribution of the sky radiance (volume particle size distribution, asymmetry factor, complex refractive index, single scattering albedo (SSA), absorption, and extinction optical depths, etc.) [42]. In this study we analyzed the aerosol optical depth (AOD), Ångström Exponent [43], volume particle size distribution, and the single scattering albedo (SSA) from the CLUJ_UBB AERONET station.

\subsection{Multi-Wavelength Raman and Depolarization Lidar}

Multi-wavelength lidar systems are active remote sensing instruments, which can provide useful information regarding the aerosol properties on different layers due to their high temporal and vertical resolutions. The Cluj-Napoca lidar system (CLOP) emission is based on a Nd-YAG laser Continuum 
INLITE II-30, which has a repetition rate of $30 \mathrm{~Hz}$ and is equipped with second and third harmonics. The radiation at 1064, 532, and $355 \mathrm{~nm}$ is simultaneously emitted into atmosphere. The backscattered radiation is collected by a Cassegrain type telescope (D300 aerosol LIDAR, Raymetrics S.A., Athens, Greece) with a focal length of $1500 \mathrm{~mm}$. The signal detection unit has a total of 6 detection channels, 4 channels for the elastically backscattered radiation at 1064, 532 (cross and parallel), and $355 \mathrm{~nm}$ and 2 channels for the Raman radiation backscattered by nitrogen molecules at 607 and $387 \mathrm{~nm}$. The raw data vertical resolution is $3.75 \mathrm{~m}$. The lidar system is part of the EARLINET [44]. For this event the measurements were made during daytime with all the elastic channels and depolarization at 532 $\mathrm{nm}$. Measurement sets of $2 \mathrm{~h}$ each were performed with a temporal resolution of $60 \mathrm{~s}$. The calibrated depolarization vertical profiles of the aerosols were computed using the method proposed by $[45,46]$.

\subsection{MODIS Retrievals}

The Moderate Resolution Imaging Spectroradiometers (MODIS) onboard NASA's Terra and Aqua platforms have been retrieving aerosol parameters since 1999 and 2002, respectively [47]. The polar orbiting satellites perform daily overpasses at 10:30 and 13:30 local solar Equatorial crossing time [48]. Retrieval products are split over land and ocean surfaces by three different sets of algorithms.

The standard Level-2 aerosol product has a $10 \mathrm{~km}$ spatial resolution, providing parameters such as total AOD at $550 \mathrm{~nm}$ and fine mode fraction based on the spectral fitting error. Other parameters may be derived from lookup tables, including Ångström Exponent, AOD at different wavelengths, and several inversion products. Detailed descriptions of the algorithms are presented extensively in the literature [47-50].

The $3 \mathrm{~km}$ product offers the same parameters as the combined land and ocean $10 \mathrm{~km}$ algorithm, using a similar structure, inversion methods, and lookup tables. Differences are found in the way reflectance pixels are selected and grouped for retrieval. This higher resolution is particularly useful for tracing fine gradients in smoke and pollution plumes, as well as in dust events. The AOD product selected for this study, Optical_Depth_Land_And_Ocean, provides the highest quality assurance confidence (QAC) for AOD at $0.55 \mu \mathrm{m}, \mathrm{QAC}=3$ over land and $\mathrm{QAC}>1$ over ocean surfaces [51]. Since a similar product for Ångström Exponent is not available at this resolution $(3 \mathrm{~km})$, the coarser 10 $\mathrm{km}$ product was used as a proxy for estimating aerosol size.

\subsection{Modelling Tools}

Hybrid Single-Particle Lagrangian Integrated Trajectory model-HYSPLIT back-trajectories were used to analyze the long-range transport of aerosols [52] and to identify the source area.

The NMMB/BSC forecast model developed by Barcelona Supercomputing Center [53] was also used in order to analyze the dynamics of this event.

\subsection{In-Situ Measurements}

During the analyzed period, in order to identify potential dry deposition of the lofted dust particles, in-situ measurements were performed with a DUSTTRAK ${ }^{\mathrm{TM}}$ DRX Aerosol Monitor optical particle counter (Model 8533 with external pump, DUSSTRAK DRX Aerosol Monitor 8533EP, TSI Incorporated, Shoreview, MN, USA) at $1.5 \mathrm{~m}$ above ground. It can simultaneously measure size segregated mass fraction concentrations $\left(\mathrm{PM}_{1}, \mathrm{PM}_{2.5}\right.$, Respirable/ $\mathrm{PM}_{4}, \mathrm{PM}_{10} /$ Thoracic, and Total PM) over a wide concentration range $\left(0.001-150 \mathrm{mg} / \mathrm{m}^{3}\right)$ in real time.

\section{Results and Discussion}

\subsection{Sun Photometer Data Analysis}

For the April the 24th 2019 at Cluj_UBB AERONET site, we analyzed Version 3, level 1.5 data, which are cloud screened and quality controlled, but without the final calibration. As seen in Figure 1a, the Aerosol Optical Depth (AOD) at $500 \mathrm{~nm}$ has a daily average of $0.26 \pm 0.02$, higher than the 0.20 
\pm 0.05 multi-annual monthly average for April at the Cluj_UBB station. Regarding the $440-870 \mathrm{~nm}$ Ångström Exponent (Figure 1b), the measured values are low $(<1)$, and specific to coarse aerosols like mineral dust. The volume size distribution (Figure 1c) is dominated by the coarse mode, and the spectral derivative of the single scattering albedo (SSA) is positive in the first part of the measurement interval (Figure 1d, 12:25 UTC), which are consistent with relatively pure mineral dust. The following spectral SSA inversion products (13:26 UTC; 13:45 UTC) exhibit a positive, then negative, spectral derivative, which indicate mixed polluted dust conditions [54,55]. The presence of fine aerosols in the mixture is also indicated by the increase in the fine mode component of the size distribution for 13:26 UTC; 13:45 UTC (Figure 1c).

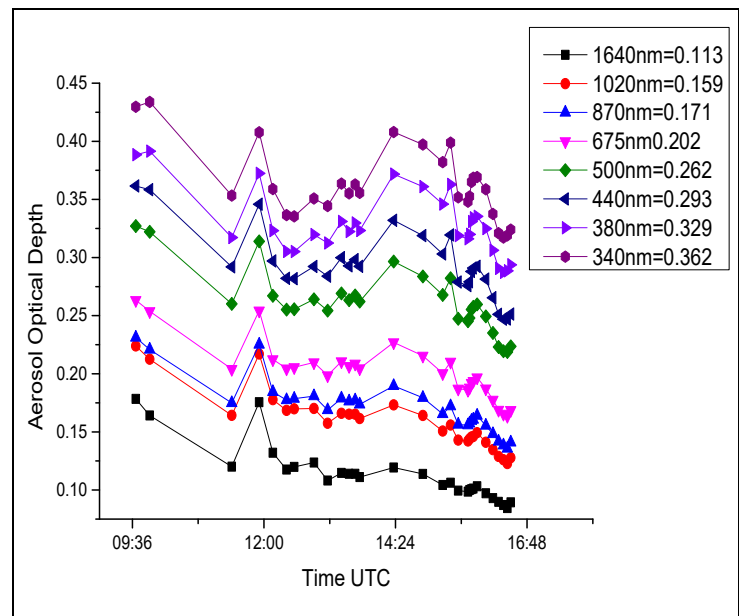

(a)

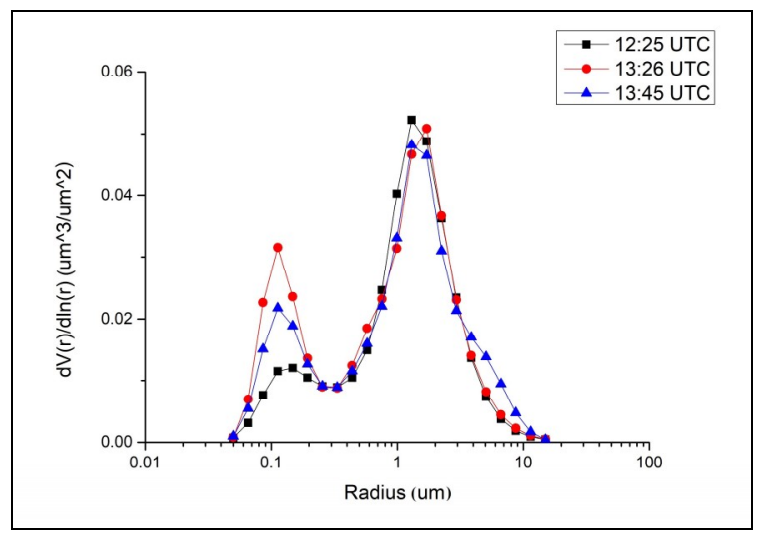

(c)

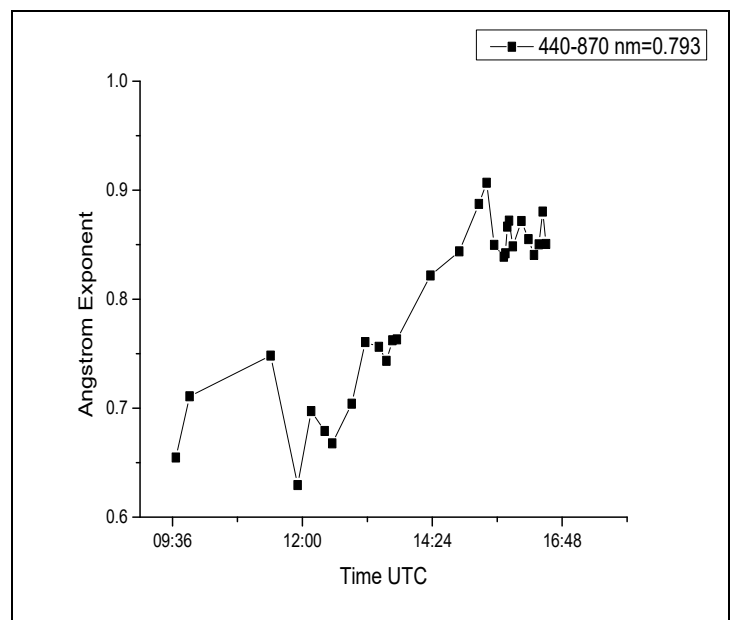

(b)

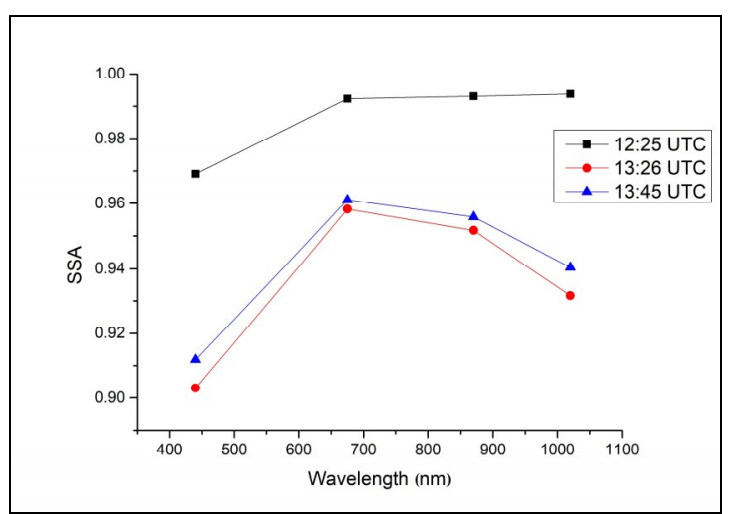

(d)

Figure 1. AERONET measurements on 24.04.2019 at CLUJ_UBB station: (a) aerosol optical depth (AOD), (b) Ångström Exponent, (c) Size distribution, (d) SSA.

\subsection{Lidar Data Analysis}

Regarding lidar measurements, in the first set (24.04.2019: 10:15-12:15 UTC), aerosol layers were observed at altitudes between 3200 and $4000 \mathrm{~m}$ at 10:15 UTC, and at altitudes from 2500 to $4000 \mathrm{~m}$ at 12:15 UTC, as seen in the Range Corrected Signals (RCS) at 1064 (Figure 2a) and $532 \mathrm{~nm}$ cross (Figure 2b). At high altitudes, between 8000 and 10,000 m we can identify high cirrus ice clouds, and below $2500 \mathrm{~m}$, two non-dust aerosol layers can be observed. 


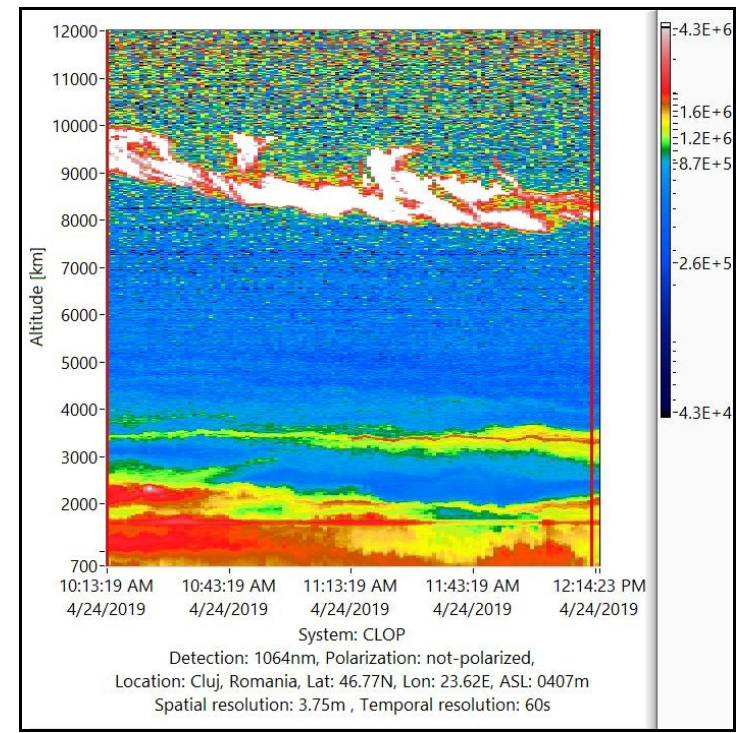

(a)

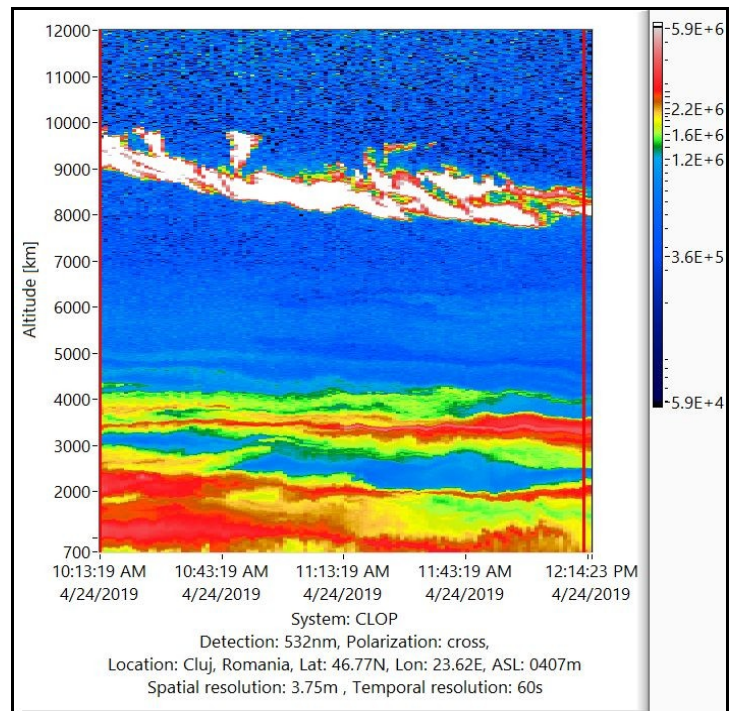

(b)

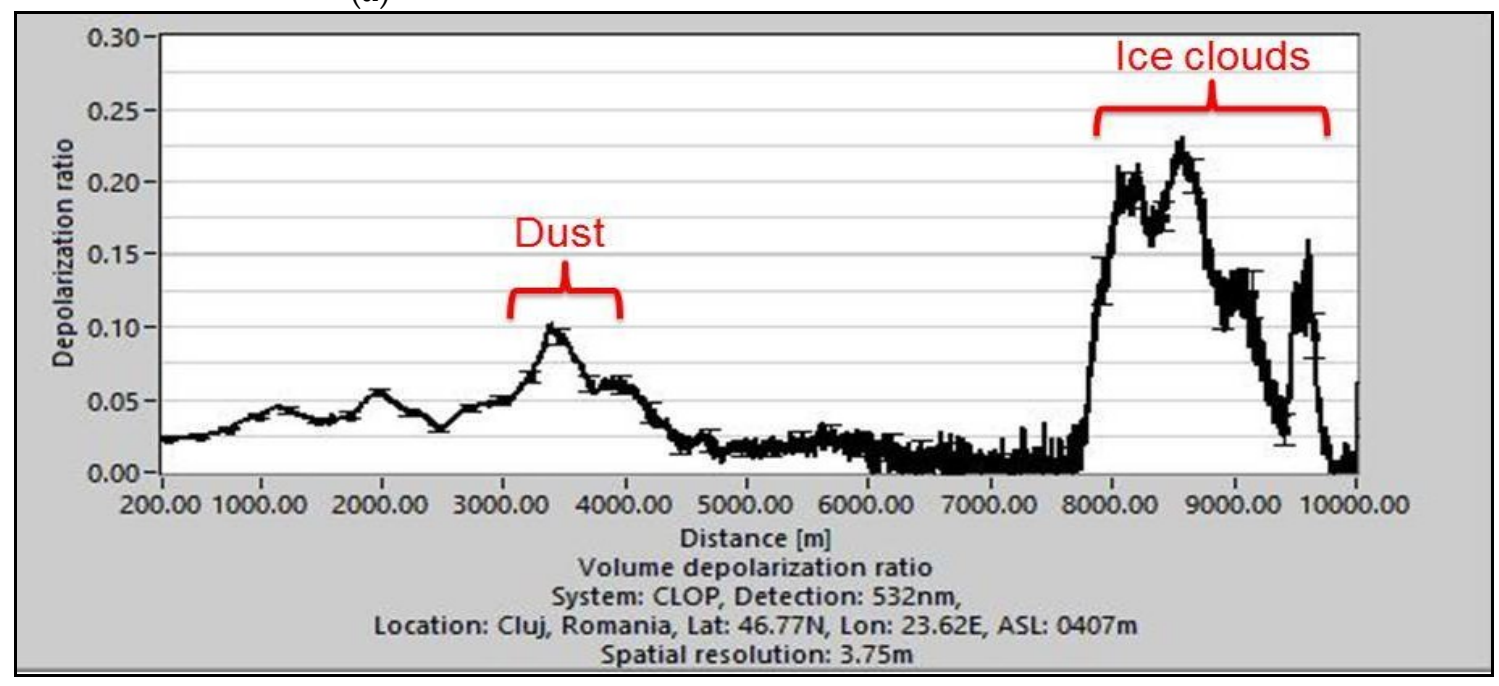

(c)

Figure 2. Cluj-Napoca lidar system (CLOP) lidar RCS for 24.04.2019: 10:15-12:15 UTC, Cluj-Napoca, $407 \mathrm{~m} \mathrm{ASL}$, at $1064 \mathrm{~nm}$ (a) and $532 \mathrm{~nm}$ cross (b); volume depolarization ratio at $532 \mathrm{~nm}$ (c).

The volume depolarization ratio (Figure 2c) for the higher aerosol layer $(2500-4000 \mathrm{~m}$ ) reaches 0.1 , characteristic to Saharan dust [56], while the lower aerosol layers (below $2500 \mathrm{~m}$ ) exhibit values of 0.05 and 0.06 , characteristic to non-dust aerosols (urban-industrial and/or biomass burning aerosols). The particle depolarization ratio for the dust aerosol layer is 0.27 , and varies between 0.1 and 0.13 for the lower non-dust aerosol layers, which are in agreement with the values presented in the literature for these aerosol types [57].

In the second lidar measurements set (24.04.2019: 12:20-14:20 UTC) we can see the same aerosol layer between 2500 and $3700 \mathrm{~m}$. In addition, a new layer is detected at higher altitude, at approx. 7000 $\mathrm{m}$, as seen in the RCS at 1064 (Figure 3a) and $532 \mathrm{~nm}$ cross (Figure 3b), below the cirrus clouds detected between 7500 and $9500 \mathrm{~m}$. The volume depolarization ratio slightly increased to 0.12 , characteristic to Saharan dust (Figure 3c). The particle depolarization ratio for the dust aerosol layer is 0.24 , which is in agreement with the values presented in the literature for this aerosol type [57]. 


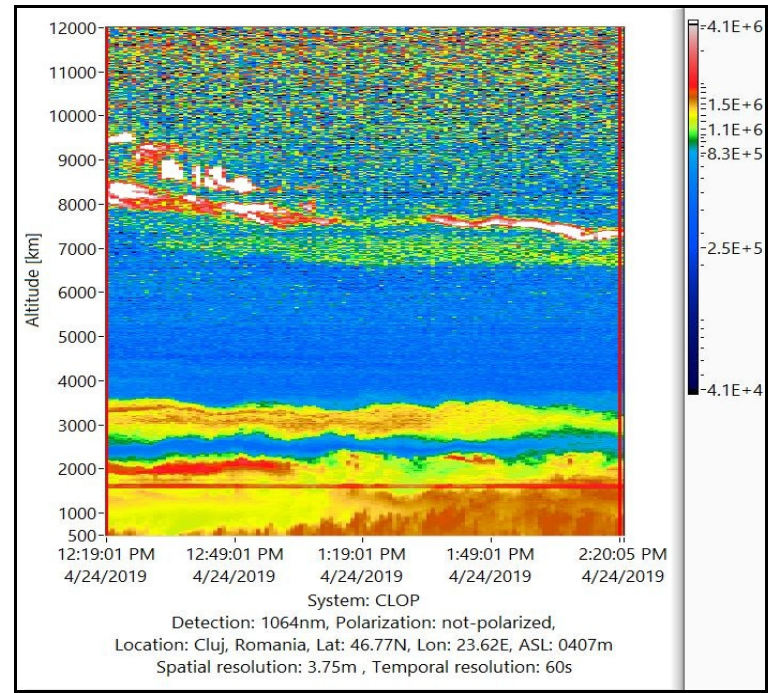

(a)

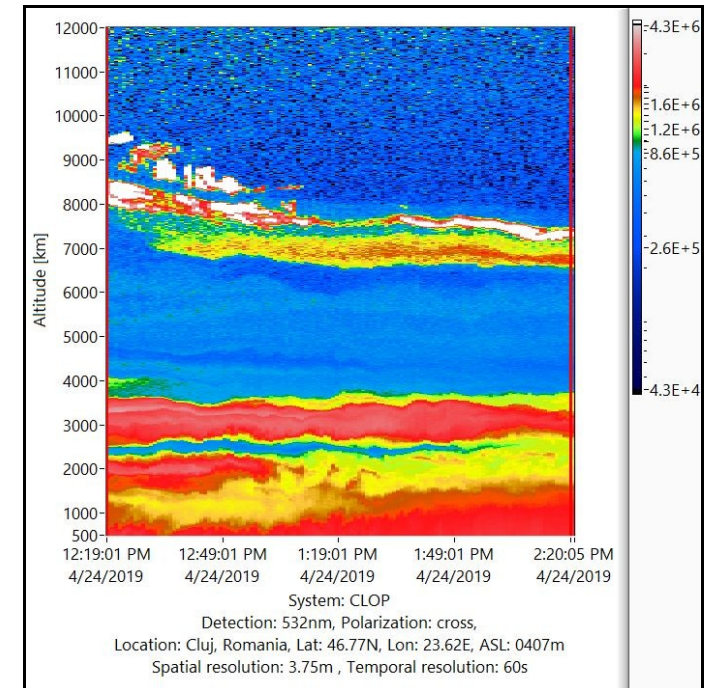

(b)

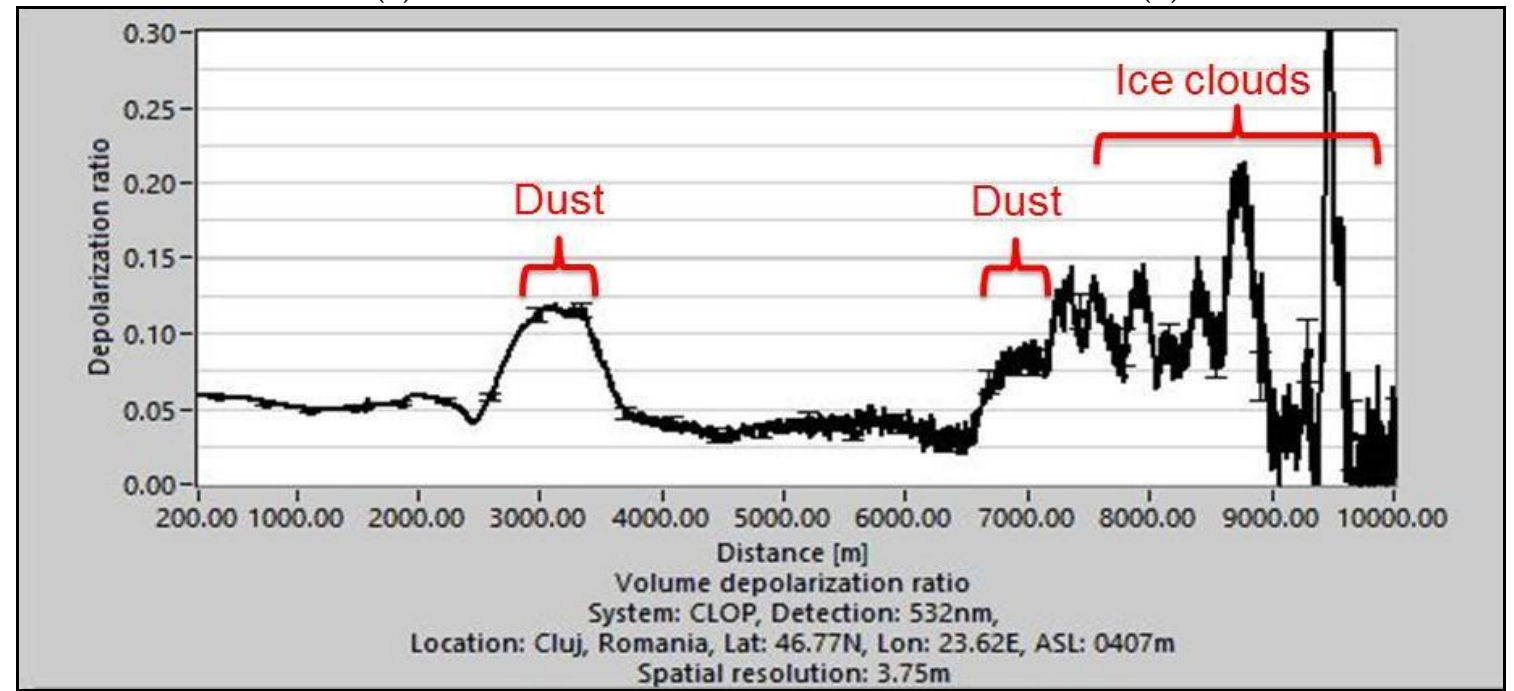

(c)

Figure 3. CLOP lidar RCS for 24.04.2019: 12:20-14:20 UTC, Cluj-Napoca, 407 m ASL, at 1064 nm (a) and $532 \mathrm{~nm}$ cross (b); volume depolarization ratio at $532 \mathrm{~nm}$ (c).

\subsection{MODIS Data Analysis}

In Figure 4, AOD values at $550 \mathrm{~nm}$ resulting from the $3 \times 3 \mathrm{~km}$ MODIS level 2 AOD products are represented. Terra MODIS retrieved AOD values between 0.19 and 0.27 over Transylvania, while Aqua MODIS showed AOD values between 0.19 and 0.33 . Within the $3 \mathrm{~h}$ gap separating the two measurements, an increase of AOD, followed by a decrease of Ångström Exponent values, seemed to indicate higher dust concentrations over the study area. This trend was observed in true color images as air masses traveled East-North East. Collocated lidar measurements (Figure 2) showed thinner layers of dust over Cluj-Napoca at 10:13 UTC, while thicker layers were observed two hours later (Figure 3). Both AOD and Ångström Exponent satellite data showed strong correlation with the equivalent AERONET parameters [58]. 


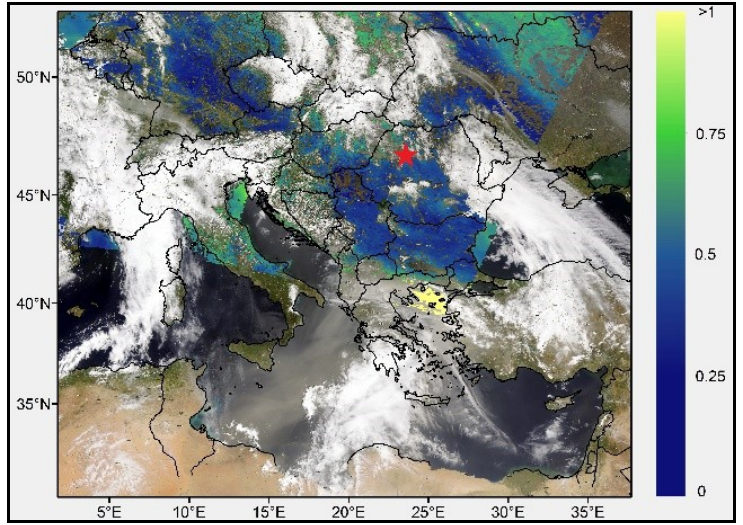

(a)

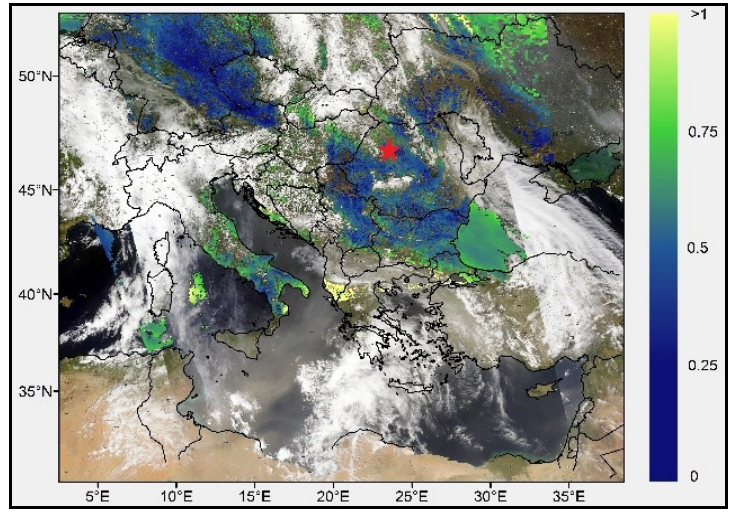

(b)

Figure 4. AOD MODIS Terra (a) and Aqua (b) for April the 24th 2019.

The particle size can be estimated using the Ångström Exponent, as this parameter is inversely related to the particle size. Regarding the range of observed values, because of the relatively low values of Ångström Exponent (less than 1), it is inferred that the majority of particles are coarse. Furthermore, the range of AOD values indicates that the thickness/density of particles in the air does not reach a critical threshold (which leads to an intense decrease in visibility) yet.

In Figure 5 the Ångström Exponent values derived from the $10 \times 10 \mathrm{~km}$ MODIS level 2 AOD products are superimposed over a true color image of Eastern Europe. A large mass of dust aerosols can be observed over the Mediterranean Sea and The Balkans. The satellite sensor onboard Terra and Aqua retrieved aerosol parameters at 10:00 UTC and 11:45 UTC, respectively. Terra MODIS retrievals exhibit Ångström Exponent values between 0 and 1.5 over Romania, with lower values ranging from 0 to 1.2 over Transylvania. Aqua MODIS retrievals exhibit Ångström Exponent values between 0 and 1.2 over Romania, with lower values ranging from 0 to 0.95 over Transylvania. These values are consistent with ones reported in the literature for mineral dust [59]. Considering that the dust particle size is usually much bigger in comparison with urban-industrial and biomass burning aerosol, it can be concluded that the analyzed dust plume is not severely polluted nor heavily mixed with smoke.

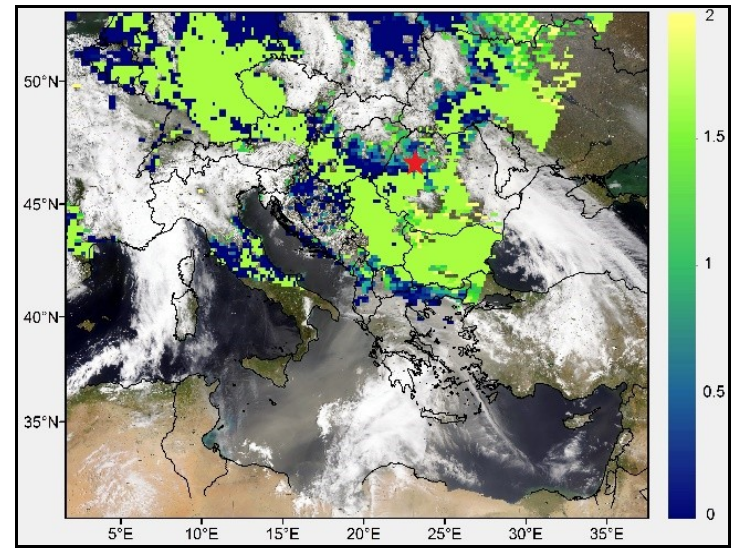

(a)

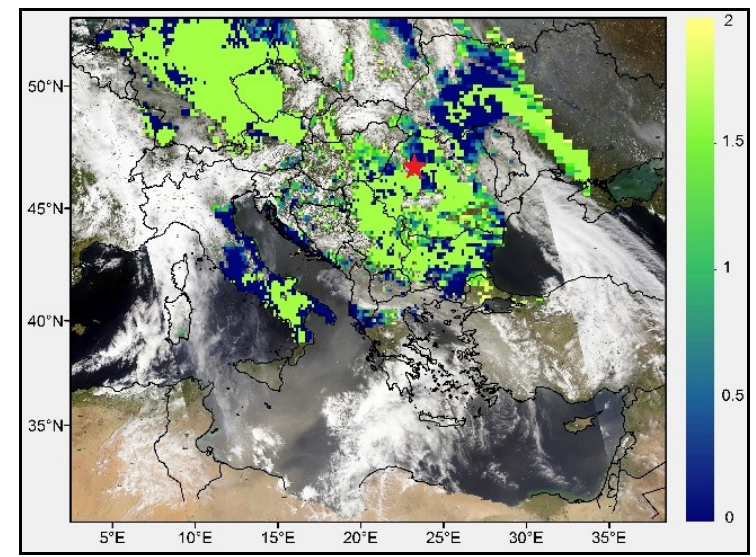

(b)

Figure 5. Ångström Exponent MODIS Terra (a) and Aqua (b) for April the 24th 2019.

\subsection{Modelling Data Analysis}

The NMMB/BSC dust model [53] predicted the Saharan dust event, as seen in Figure 6. The cyclonic nucleus developed over north-western Africa on April the 20th 2019 (marked with blue arrows in Figure 6a), and lifted up a significant amount of dust that was carried out by upper level southern and 
south-western circulation (emphasized by blue arrow in Figure $6 \mathrm{~b}$ ). The dust intrusion covered many parts of Europe, including Transylvania. The model predicted a dust load value between 1 and $1.5 \mathrm{~g} / \mathrm{m}^{2}$ over Cluj-Napoca at 12:00 UTC for April the 24th 2019. The $700 \mathrm{hPa}$ wind is the level that corresponds to the layer centered on $3000 \mathrm{~m}$, where the CLOP lidar detected the first dust layer in Figure 3. The south-western circulation over the same area was revealed also at $400 \mathrm{hPa}$ level, corresponding with the altitude of $7000 \mathrm{~m}$ (not shown here).

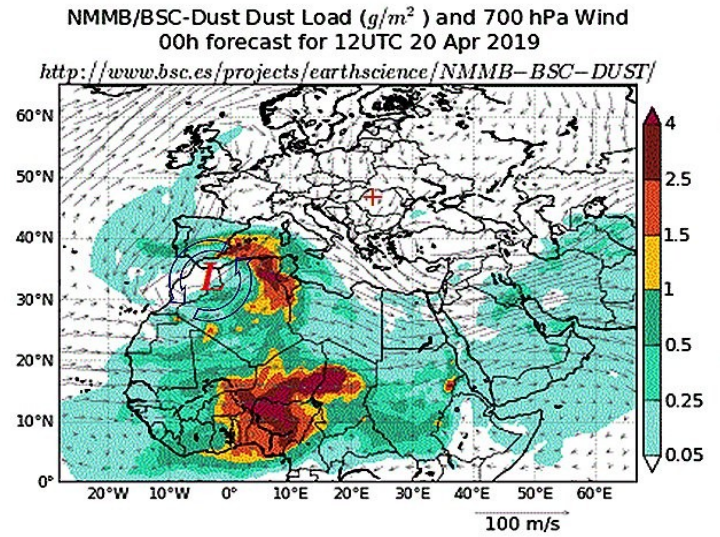

(a)

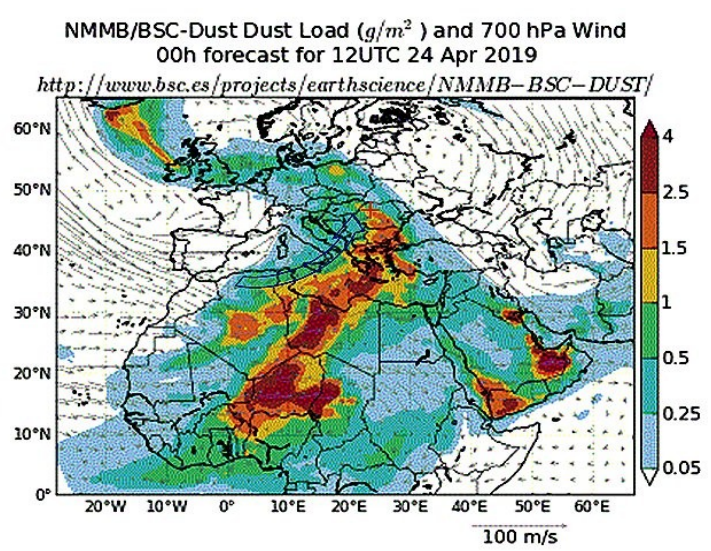

(b)

Figure 6. NMMB/BSC model dust load (pallete) and $700 \mathrm{hPa}$ circulation (black arrows) for 20.04.2019, $12 \operatorname{UTC}(\mathbf{a})$, and (b) for 24.04.2019, 12:00 UTC.

In order to determine the origin of the mineral dust layers detected over Cluj-Napoca, we used the NOAA HYSPLIT back-trajectories model. The back-trajectories (Figure 7) show that the air masses present over Transylvania-Cluj-Napoca station on April the 24th 2019 during the lidar measurements originated from the Saharan desert. Similar to the [60] study, we can analyze the air masses dynamics using Figure 7. For the trajectories that were obtained for a period of $72 \mathrm{~h}$ backward in time, the traveling time from the African continent to the detection station (after leaving the African continent) is less than $48 \mathrm{~h}$, which comes in support of the previous assumption that the dust plume is relatively pure.
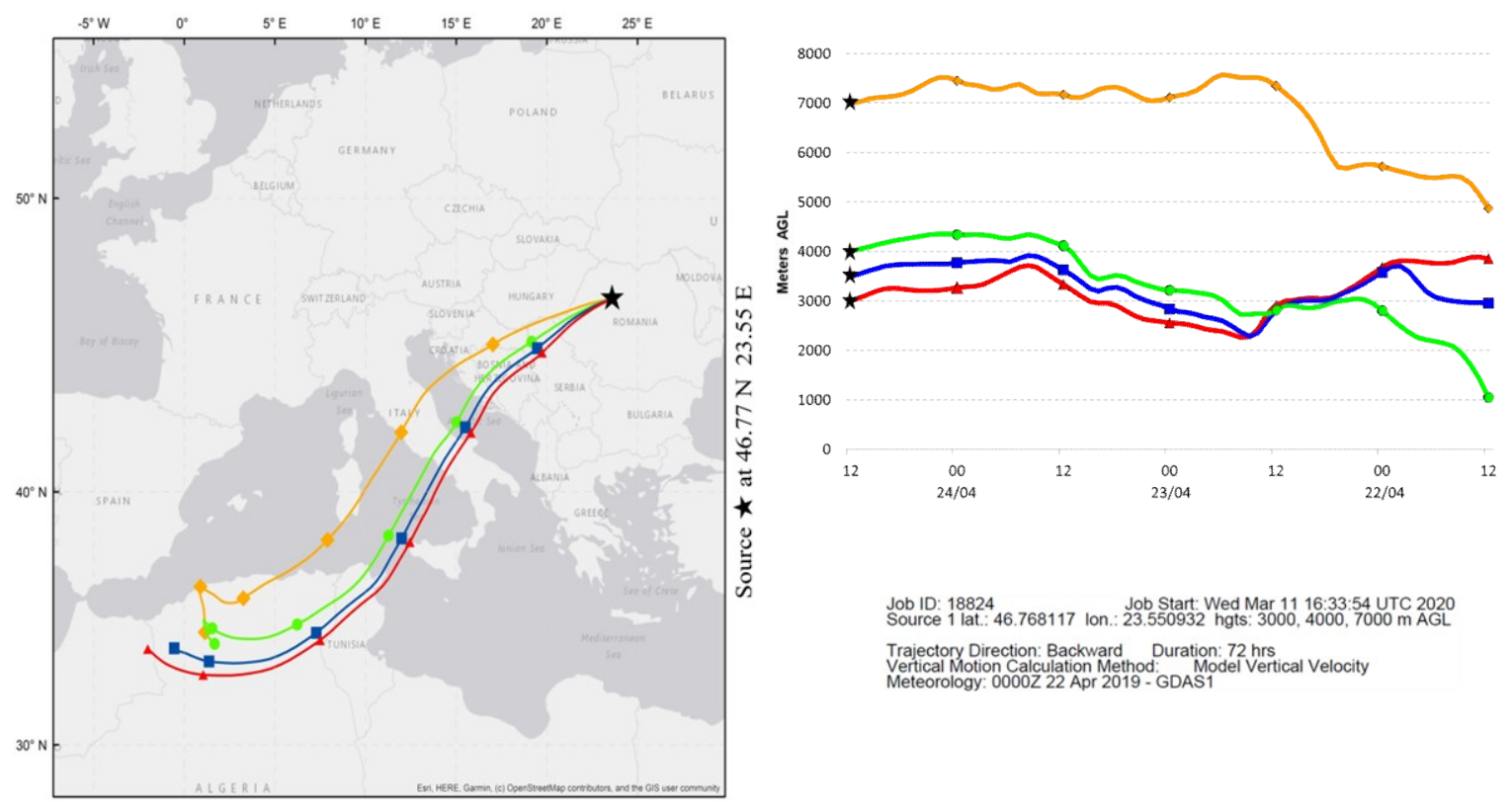

Job ID: 18824
Source 1 lat: 46.768117 Ion.: 23.550932 hgts: $3000,4000,7000$ m AGL

Trajectory Direction: Backward Duration: 72 hrs
Vertical Motion Calaluation Method: Model Vertical Velocity
Meteorology: $0000 Z 22$ Apr 2019-GDAS1

Figure 7. HYSPLIT back-trajectories obtained for 24.04.2019 at 12:00 UTC. 


\subsection{In-Situ Ground Measurements Analysis}

Regarding the in-situ ground level particulate matter values, during the dust intrusion on April the 24th 2019 we measured low values of $\mathrm{PM}_{10}$ and $\mathrm{PM}_{2.5}$ with an hourly average of $21 \mu \mathrm{g} / \mathrm{m}^{3}$ for both $\mathrm{PM}_{10}$ and $\mathrm{PM}_{2.5}$ and a maximum of $28 \mu \mathrm{g} / \mathrm{m}^{3}$ for $\mathrm{PM}_{10}$ and $27 \mu \mathrm{g} / \mathrm{m}^{3}$ for $\mathrm{PM}_{2.5}$. These values are consistent with other measurements reported for Cluj-Napoca city during the period for which data was available from the National Air Quality Network [61]. We can therefore conclude that there was a very limited dry deposition of Saharan dust particles in Cluj-Napoca during this event, and the high-altitude transport continued further north.

\section{Conclusions}

In this paper, we analyzed a severe dust outbreak over Transylvania, Romania, during April 2019, using multiple remote sensing and in-situ instrumentation supported by modelling tools. These results can also be considered representative for the Pannonian basin.

Results show the presence of dust aerosol layers identified by the multi-wavelength Raman and depolarization lidar at altitudes of $2500-4000 \mathrm{~m}$, and $7000 \mathrm{~m}$, respectively.

An analysis of the optical and microphysical columnar properties from AERONET reveals an increase in the aerosol optical depth (AOD), but the AOD range indicates that the density of lofted dust particles has not reached a critical threshold that would affect visibility. Sun-photometer measurements exhibit low values of the Ångström Exponent $(<1)$ and a dominant coarse mode $(>1 \mu \mathrm{m})$ in the AERONET particle size distribution.

For the dust layers observed, the volume linear depolarization ratio obtained from the lidar's 532 $\mathrm{nm}$ channel is $0.1-0.12$, which is characteristic for mineral dust. The $532 \mathrm{~nm}$ particle depolarization ratio is $0.24-0.27$, and remains relatively constant within the dust layers, indicating that the mineral dust particles are evenly spread.

The variations in the spectral derivative of the SSA, along with lidar information about the presence and depolarization characteristics of non-dust layers below $2500 \mathrm{~m}$ indicate the presence of biomass burning and/or urban-industrial aerosols below $2500 \mathrm{~m}$. Therefore, it can be concluded that the dust layers above $2500 \mathrm{~m}$ are neither severely polluted nor heavily mixed with smoke.

The analysis of the MODIS retrievals provides added value information on the spatial distribution of the aerosol optical properties (AOD and Ångström Exponent) over Transylvania, and is in agreement with the AERONET ground-based measurements from Cluj-Napoca.

Based on these results, and on the HYSPLIT back-trajectory, NMMB/BSC forecast, and synoptic analysis, we can confirm the presence of lofted Saharan dust layers over Cluj-Napoca, Romania during the April 2019 outbreak.

Collocated in-situ PM monitoring carried out with an optical particle counter showed that dry deposition was low, with $\mathrm{PM}_{10}$ and $\mathrm{PM}_{2.5}$ concentrations similar to the seasonal averages for Cluj-Napoca.

The case analysis carried out in this paper can be an example of a comprehensive monitoring and characterization of the Saharan dust plume in the north-western part of Romania. The results of this article provide a variety of geo-spatial, temporal and qualitative information on the Saharan dust intrusion in the Transylvania and Pannonian basins. This source of information, obtained from various multi-modal datasets, can help in the forecast and management of this natural hazard in a more efficient way.

Author Contributions: Conceptualization, N.A. and C.B.; Methodology, N.A. and H.Ș.; Visualization, A.R. and A.M., Writing-Review and Editing, N.A., C.B. and H.S. All authors have read and agreed to the published version of the manuscript.

Funding: This research was conducted using the research infrastructure purchased within the POSCCE Project entitled "Development of Research Infrastructure for HPC-Based Disaster Management" - MADECIP, SMIS CODE 48801/1862, co-financed by the European Union through the European Regional Development Fund. This work 
was partially supported by a grant of the Romanian Ministry of Research and Innovation, CCCDI - UEFISCDI, project number 87 PCCDI/2018, project registration code PN-III-P1-1.2-PCCDI-2017-0868, within PNCDI III.

Acknowledgments: The authors gratefully acknowledge the NOAA Air Resources Laboratory (ARL) for the provision of the HYSPLIT transport and dispersion model and READY website (http://www.ready.noaa.gov) used in this publication. Images from the NMMB/BSC-Dust model, operated by the Barcelona Supercomputing Center (http://www.bsc.es/ess/bsc-dust-daily-forecast/) were used in this study. AERONET-Europe/ACTRIS for calibration and maintenance services. The research leading to these results has received funding from European Union's Horizon 2020 research and innovation programme under grant agreement No 654109. The authors would like to acknowledge Simona Andrei, from the National Institute for R\&D in Optoelectronics-INOE2000, Magurele, $\mathrm{RO}$ for her help in the synoptic analysis.

Conflicts of Interest: The authors declare no conflict of interest.

\section{References}

1. Intergovernmental Panel on Climate Change. Climate Change 2013-The Physical Science Basis: Working Group I Contribution to the Fifth Assessment Report of the Intergovernmental Panel on Climate Change; Cambridge University Press: Cambridge, UK; New York, NY, USA, 2014. [CrossRef]

2. Díaz, J.; Linares, C.; Carmona, R.; Russo, A.; Ortiz, C.; Salvador, P.; Trigo, R.M. Saharan dust intrusions in Spain: Health impacts and associated synoptic conditions. Environ. Res. 2017, 156, 455-467. [CrossRef] [PubMed]

3. Stafoggia, M.; Zauli-Sajani, S.; Pey, J.; Samoli, E.; Alessandrini, E.; Basagaña, X.; Cernigliaro, A.; Chiusolo, M.; Demaria, M.; Díaz, J.; et al. MED-PARTICLES Study Group. Desert dust outbreaks in Southern Europe: Contribution to daily PM10 concentrations and short-term associations with mortality and hospital admissions. Environ. Health Perspect. 2016, 124, 413-419. [CrossRef] [PubMed]

4. Ai, N.; Polenske, K.R. Socioeconomic impact analysis of yellow-dust storms: An approach and case study for Beijing. Econ. Syst. Res. 2008, 20, 187-203. [CrossRef]

5. Al-Hemoud, A.; Al-Sudairawi, M.; Neelamanai, S.; Naseeb, A.; Behbehani, W. Socioeconomic effect of dust storms in Kuwait. Arab. J. Geosci. 2017, 10, 18. [CrossRef]

6. Andreae, M. Climate effects of changing atmospheric aerosol levels. In World Survey of Climatology, Future Climate of the World; Henderson Sellers, A.H., Ed.; Elsevier: New York, NY, USA, 1995; Volume 16, pp. $341-392$.

7. Nicolae, V.; Talianu, C.; Andrei, S.; Antonescu, B.; Ene, D.; Nicolae, D.; Dandocsi, A.; Toader, V.-E.; Ștefan, S.; Savu, T.; et al. Multiyear Typology of Long-Range Transported Aerosols over Europe. Atmosphere 2019, 10, 482. [CrossRef]

8. Papayannis, A.; Amiridis, V.; Mona, L.; Tsaknakis, G.; Balis, D.; Bösenberg, J.; Chaikovski, A.; De Tomasi, F.; Grigorov, I.; Mattis, I.; et al. Systematic lidar observations of Saharan dust over Europe in the frame of EARLINET (2000-2002). J. Geophys. Res. 2008, 113. [CrossRef]

9. Salvador, P.; Almeida, S.M.; Cardoso, J.; Almeida-Silva, M.; Nunes, T.; Cerqueira, M.; Alves, C.; Reis, M.A.; Chaves, P.C.; Artinano, B.; et al. Composition and origin of PM10 in Cape Verde: Characterization of long-range transport episodes. Atmos. Environ. 2016, 127, 326-339. [CrossRef]

10. Ravi, S.; D'Odorico, P.; Breshears, D.D.; Field, J.P.; Goudie, A.S.; Huxman, T.E.; Li, J.; Okin, G.S.; Swap, R.J.; Thomas, A.D.; et al. Aeolian processes and the biosphere. Rev. Geophys. 2011, 49, RG3001. [CrossRef]

11. Shao, Y.; Wyrwoll, K.-H.; Chappell, A.; Huang, J.; Lin, Z.; Mctainsh, G.H.; Mikami, M.; Tanaka, T.Y.; Wang, X.; Yoon, S. Dust cycle: An emerging core theme in Earth system science. Aeolian Res. 2011, 2, 181-204. [CrossRef]

12. Querol, X.; Pey, J.; Pandolfi, M.; Alastuey, A.; Cusack, M.; Pérez, N.; Moreno, T.; Viana, M.; Mihalopoulos, N.; Kallos, G.; et al. African dust contributions to mean ambient PM10 mass-levels across the Mediterranean Basin. Atmos. Environ. 2009, 43, 4266-4277. [CrossRef]

13. Kallos, G.; Astitha, M.; Katsafados, P.; Spyrou, C. Long-Range Transport of Anthropogenically and Naturally Produced Particulate Matter in the Mediterranean and North Atlantic: Current State of Knowledge. J. Appl. Meteorol. Clim. 2007, 46, 1230-1251. [CrossRef]

14. Lamancusa, C.; Wagstrom, K. Global transport of dust emitted from different regions of the Sahara. Atmos. Environ. 2019, 214, 1-10. [CrossRef]

15. Sicard, M.; Barragan, R.; Dulac, F.; Alados-Arboledas, L.; Mallet, M. Aerosol optical, microphysical and radiative properties at regional background insular sites in the western Mediterranean. Atmos. Chem. Phys. 2016, 16, 12177-12203. [CrossRef] 
16. Cuevas, E.; Gómez-Peláez, A.J.; Rodríguez, S.; Terradellas, E.; Basart, S.; Garcia, R.D.; Garcia, O.E.; Alonso-Perez, S. The pulsating nature of large-scale Saharan dust transport as a result of interplays between mid-latitude Rossby waves and the North African Dipole Intensity. Atmos. Environ. 2017, 167, $586-602$. [CrossRef]

17. Mona, L.; Amodeo, A.; Pandolfi, M.; Pappalardo, G. Saharan dust intrusions in the Mediterranean area: Three years of Raman lidar measurements. J. Geophys. Res. 2006, 111, D16. [CrossRef]

18. Marinou, E.; Amiridis, V.; Binietoglou, I.; Tsikerdekis, A.; Solomos, S.; Proestakis, E.; Konsta, D.; Papagiannopoulos, N.; Tsekeri, A.; Vlastou, G.; et al. Three-dimensional evolution of Saharan dust transport towards Europe based on a 9-year EARLINET-optimized CALIPSO dataset. Atmos. Chem. Phys. 2017, 17, 5893-5919. [CrossRef]

19. Israelevich, P.; Ganor, E.; Alpert, P.; Kishcha, P.; Stupp, A. Predominant transport paths of Saharan dust over the Mediterranean Sea to Europe. J. Geophys. Res. 2012, 117, 2205. [CrossRef]

20. Janicka, L.; Stachlewska, I.S.; Veselovskii, I.; Baars, H. Temporal variations in optical and microphysical properties of mineral dust and biomass burning aerosol derived from daytime Raman lidar observations over Warsaw, Poland. Atmos. Environ. 2017, 169, 162-174. [CrossRef]

21. Osborne, M.; Malavelle, F.F.; Adam, M.; Buxmann, J.; Sugier, J.; Marenco, F.; Haywood, J. Saharan dust and biomass burning aerosols during ex-hurricane Ophelia: Observations from the new UK lidar and sun-photometer network. Atmos. Chem. Phys. 2019, 19, 3557-3578. [CrossRef]

22. Bègue, N.; Tulet, P.; Chaboureau, J.-P.; Roberts, G.; Gomes, L.; Mallet, M. Long-range transport of Saharan dust over northwestern Europe during EUCAARI 2008 campaign: Evolution of dust optical properties by scavenging. J. Geophys. Res. 2012, 117, D17201. [CrossRef]

23. Abdelkader, M.; Metzger, S.; Mamouri, R.E.; Astitha, M.; Barrie, L.; Levin, Z.; Lelieveld, J. Dust-air pollution dynamics over the eastern Mediterranean. Atmos. Chem. Phys. 2015, 15, 9173-9189. [CrossRef]

24. Ștefănie, H.; Ajtai, N.; Botezan, C.; Țoancă, F.; Török, Z.; Ozunu, A. Detection of a desert dust intrusion over ClujNapoca, Romania using an elastic backscatter LIDAR system. Ecoterra-J. Environ. Res. Prot. 2015, 12, 50-55.

25. Tudose, O.G. Contributions to the Study of Atmospheric Aerosols Optical Properties Using Remote Sensing Techniques. Ph.D. Thesis, Alexandru Ioan Cuza University of Iasi, Iasi, Romania, 2013.

26. Rogora, M.; Mosello, R.; Marchetto, A. Long-term trends in the chemistry of atmospheric deposition in Northwestern Italy: The role of increasing Saharan dust deposition. Tellus B Chem. Phys. Meteorol. 2004, 56, 426-434. [CrossRef]

27. Papagiannopoulos, N.; D'Amico, G.; Gialitaki, A.; Ajtai, N.; Alados-Arboledas, L.; Amodeo, A.; Amiridis, V.; Baars, H.; Balis, D.; Binietoglou, I.; et al. An EARLINET Early Warning System for atmospheric aerosol aviation hazards. Atmos. Chem. Phys. Discuss. 2020. in review. [CrossRef]

28. Cazacu, M.M.; Tudose, O.G.; Timofte, A.; Rusu, O.; Apostol, L.; Leontie, L.; Gurlui, S. A case study of the behavior of aerosol optical properties under the incidence of a saharan dust intrusion event. Appl. Ecol. Environ. Res. 2016, 14, 183-194. [CrossRef]

29. Labzovskii, L.; Toanca, F.; Nicolae, D. Determination of saharan dust properties over bucharest, Romania part 2: Study cases analysis. Rom. J. Phys. 2014, 59, 1097-1108.

30. Gothard, M.; Nemuc, A.; Radu, C.; Dascalu, S. An intensive case of saharan dust intrusion over south east Romania. Rom. Rep. Phys. 2014, 66, 509-519.

31. Rosu, I.A.; Cazacu, M.M.; Prelipceanu, O.S.; Agop, M. A Turbulence-Oriented Approach to Retrieve Various Atmospheric Parameters Using Advanced Lidar Data Processing Techniques. Atmosphere 2019, 10, 38. [CrossRef]

32. Ajtai, N.; Stefanie, H.; Arghius, V.; Meltzer, M.; Costin, D. Characterization of Aerosol Optical and Microphysical Properties Over North-Western Romania In Correlation with Predominant Atmospheric Circulation Patterns. In Proceedings of the 17th International Multidisciplinary Scientific Geoconference (SGEM 2017), Albena, Bulgaria, 29 June-5 July 2017. [CrossRef]

33. Ajtai, N.; Ștefănie, H.; Ozunu, A. Description of aerosol properties over Cluj-Napoca derived from AERONET sun photometric data. Environ. Eng. Manag. J. 2013, 12, 227-232. [CrossRef]

34. Talianu, C.; Nemuc, A.; Nicolae, D.; Cristescu, C.P. Dust Event Detection from Lidar Measurements. Sci. Bull. Politeh. Univ. Buchar. Ser. A Appl. Math. Phys. 2007, 69, 53-62. 
35. Cazacu, M.M.; Tudose, O.; Boscornea, A.; Buzdugan, L.; Timofte, A.; Nicolae, D. Vertical and temporal variation of aerosol mass concentration at Magurele-Romania during EMEP/PEGASOS campaign. Rom. Rep. Phys. 2017, 69, 1-15.

36. Mărmureanu, L.; Marin, C.A.; Andrei, S.; Antonescu, B.; Ene, D.; Boldeanu, M.; Vasilescu, J.; Vițelaru, C.; Cadar, O.; Levei, E. Orange Snow-A Saharan Dust Intrusion over Romania During Winter Conditions. Remote Sens. 2019, 11, 2466. [CrossRef]

37. Severe Weather Europe. Available online: http://www.severe-weather.eu/mcd/extent-of-airborne-saharandust-over-europe-on-wednesday-and-thursday/ (accessed on 3 October 2019).

38. Pappalardo, G.; Amodeo, A.; Apituley, A.; Comeron, A.; Freudenthaler, V.; Linné, H.; Ansmann, A.; Bösenberg, J.; D'Amico, G.; Mattis, I.; et al. EARLINET: Towards an advanced sustainable 20 European aerosol lidar network. Atmos. Meas. Tech. 2014, 7, 2389-2409. [CrossRef]

39. Holben, B.N.; Eck, T.F.; Slutsker, I.; Tanre, D.; Buis, J.P.; Setzer, A.; Vermote, E.; Reagan, J.A.; Kaufman, Y.; Nakajima, T.; et al. AERONET-A federated instrument network and data archive for aerosol characterization. Remote Sens. Environ. 1998, 66,1-16. [CrossRef]

40. ACTRIS. Available online: https://www.actris.eu/ (accessed on 6 September 2019).

41. AERONET. Available online: https://aeronet.gsfc.nasa.gov/ (accessed on 12 September 2019).

42. Dubovik, O.; King, M. A flexible inversion algorithm for retrieval of aerosol optical properties from Sun and sky radiance measurements. J. Geophys. Res. 2000, 105, 20673-20696. [CrossRef]

43. Ångström, A. The parameters of atmospheric turbidity. Tellus 1964, 16, 64-75. [CrossRef]

44. European Aerosol Research Lidar Network. Available online: https://www.earlinet.org (accessed on 18 September 2019).

45. Freudenthaler, V. About the efects of polarising optics on lidar signals and the D90 calibration. Atmos. Meas. Tech. 2016, 9, 4181-4255. [CrossRef]

46. Belegante, L.; Bravo-Aranda, J.A.; Freudenthaler, V.; Nicolae, D.; Nemuc, A.; Ene, D.; Alados-Arboledas, L.; Amodeo, A.; Pappalardo, G.; D'Amico, G.; et al. Experimental techniques for the calibration of lidar depolarization channels in EARLINET. Atmos. Meas. Tech. 2018, 11, 1119-1141. [CrossRef]

47. Sayer, A.M.; Munchak, L.A.; Hsu, N.C.; Levy, R.C.; Bettenhausen, C.; Jeong, M.-J. MODIS Collection 6 aerosol products: Comparison between Aqua's e-Deep Blue, Dark Target, and merged data sets, and usage recommendations. J. Geophys. Res. 2014, 119, 13965-13989. [CrossRef]

48. Levy, R.C.; Remer, L.A.; Tanré, D.; Mattoo, S.; Kaufman, Y.J. Algorithm for Remote Sensing of Tropospheric Aerosol over Dark Targets from MODIS: Collections 005 and 051: Revision 2; MODIS Algorithm Theoretical Basis Document. 2009. Available online: https:/atmosphere-imager.gsfc.nasa.gov/sites/default/files/ ModAtmo/ATBD_MOD04_C005_rev2_0.pdf (accessed on 3 October 2019).

49. Levy, R.C.; Mattoo, S.; Munchak, L.A.; Remer, L.A.; Sayer, A.M.; Patadia, F.; Hsu, N.C. The Collection 6 MODIS aerosol products over land and ocean. Atmos. Meas. Tech. 2013, 6, 2989-3034. [CrossRef]

50. Hsu, N.C.; Jeong, M.-J.; Bettenhausen, C.; Sayer, A.M.; Hansell, R.; Seftor, C.S.; Huang, J.; Tsay, S.-C. Enhanced Deep Blue aerosol retrieval algorithm: The second generation. J. Geophys. Res. Atmos. 2013, 118, 9296-9315. [CrossRef]

51. Remer, L.A.; Mattoo, S.; Levy, R.C.; Munchak, L.A. MODIS 3 km aerosol product: Algorithm and global perspective. Atmos. Meas. Tech. 2013, 6, 1829-1844. [CrossRef]

52. Draxler, R.R.; Rolph, G.D. HYSPLIT (HYbrid Single-Particle Lagrangian Integrated Trajectory) Model Access via NOAA ARL READY Website. NOAA Air Resources Laboratory. 2015; College Park. Available online: http://www.arl.noaa.gov/HYSPLIT.php (accessed on 11 March 2020).

53. Pérez, C.; Haustein, K.; Janjic, Z.; Jorba, O.; Huneeus, N.; Baldasano, J.M.; Black, T.; Basart, S.; Nickovic, S.; Miller, R.L.; et al. An online mineral dust aerosol model for meso to global scales: Model description, annual simulations and evaluation. Atmos. Chem. Phys. 2011, 11, 13001-13027. [CrossRef]

54. Dubovik, O.; Holben, B.; Eck, T.; Smirnov, A.; Kaufman, Y.; King, M.; Tanré, D.; Slutsker, I. Variability of Absorption and Optical Properties of Key Aerosol Types Observed in Worldwide Locations. J. Atmos. Sci. 2002, 59, 590-608. [CrossRef]

55. Li, J.; Carlson, B.E.; Lacis, A.A. Using single-scattering albedo spectral curvature to characterize East Asian aerosol mixtures. J. Geophys. Res. Atmos. 2015, 120, 2037-2052. [CrossRef] 
56. Groß, S.; Gasteiger, J.; Freudenthaler, V.; Wiegner, M.; Geiß, A.; Schladitz, A.; Toledano, C.; Kandler, K.; Tesche, M.; Ansmann, A.; et al. Characterization of the planetary boundary layer during SAMUM-2 by means of lidar measurements. Tellus B 2011, 63, 695-705. [CrossRef]

57. Tesche, M.; Gross, S.; Ansmann, A.; Müller, D.; Althausen, D.; Freudenthaler, V.; Esselborn, M. Profiling of Saharan dust and biomass-burning smoke with multiwavelength polarization Raman lidar at Cape Verde. Tellus B Chem. Phys. Meteorol. 2011, 63, 649-676. [CrossRef]

58. Li, L.; Sokolik, I. Analysis of Dust Aerosol Retrievals Using Satellite Data in Central Asia. Atmosphere 2018, 9, 288. [CrossRef]

59. Kalashnikova, O.V.; Kahn, R.A. Mineral dust plume evolution over the Atlantic from MISR and MODIS aerosol retrievals. J. Geophys. Res. 2008, 113, D24. [CrossRef]

60. Soupiona, O.; Samaras, S.; Ortiz-Amezcua, P.; Böckmann, C.; Papayannis, A.; Moreira, G.A.; Benavent-Oltra, J.A.; Guerrero-Rascado, J.L.; Bedoya-Velasquez, A.E.; Olmo, F.J.; et al. Retrieval of optical and microphysical properties of transported Saharan dust over Athens and Granada based on multi-wavelength Raman lidar measurements: Study of the mixing processes. Atmos. Environ. 2019, 214, 116824. [CrossRef]

61. Calitate Aer. Available online: www.calitateaer.ro (accessed on 25 September 2019).

(C) 2020 by the authors. Licensee MDPI, Basel, Switzerland. This article is an open access article distributed under the terms and conditions of the Creative Commons Attribution (CC BY) license (http://creativecommons.org/licenses/by/4.0/). 